\title{
PENINGKATAN WAWASAN TERHADAP COMPUTER VISION SINDROME BAGI PENGGUNA KOMPUTER GUNA MENGHINDARI TERJADINYA GANGGUAN PENGLIHATAN
}

\author{
Meriana Rasyid $^{1}$, Novendy ${ }^{2}$, Enny Irawaty ${ }^{3}$ dan Susy Olivia Lontoh ${ }^{4}$ \\ ${ }^{1}$ Bagian Ilmu Penyakit Mata Fakultas Kedokteran Universitas Tarumanagara \\ Email: merirasyid@gmail.com \\ ${ }^{2}$ Bagian Ilmu Kesehatan Masyarakat, Fakultas Kedokteran Universitas Tarumanagara, Jakarta \\ Email: novendy@fk.untar.ac.id \\ ${ }^{3}$ Bagian Ilmu Faal, Fakultas Kedokteran Universitas Tarumanagara, Jakarta \\ Email: ennyi@fk.untar.ac.id \\ ${ }^{4}$ Bagian Ilmu Faal, Fakultas Kedokteran Universitas Tarumanagara, Jakarta \\ Email: susyo@fk.untar.ac.id
}

\begin{abstract}
The work system and learning activities from home that are widely carried out now due to the Covid-19 pandemic require us to carry out study activities, work, daily routines at home. A person can do work sitting in front of a computer or laptop for more than 8 hours a day, this situation causes vision problems, namely computer vision syndrome. Based on the problems above, it is necessary to carry out an outreach activity related to knowledge about CVS. This activity aims to improve the individual's health status, educate them to pay attention to eye health and add insight by providing education related to CVS knowledge and preventive actions to reduce the incidence of CVS. The target of the activity is the community, especially young adults who in their daily activities use computers. The implementation activity was carried out on April 10, 2021 and was attended by 35 participants, most of whom were students. The results of this health service activity indicate an increase in participants' knowledge about this CVS disease. This can be seen from the increase in knowledge by 50\% from the results of the pretest and posttest. This increase in knowledge is expected to make computer users more aware when these eye disorders appear and can seek help so that problems do not occur in the future.
\end{abstract}

Keywords: computer vision syndrome, counseling, prevention

\begin{abstract}
ABSTRAK
Sistem kerja dan kegiatan pembelajaran dari rumah yang banyak dijalankan sekarang akibat pandemi Covid -19 menuntut kita melakukan aktivitas belajar, pekerjaan, rutinitas seharihari di rumah. Seseorang dapat melakukan pekerjaan duduk di depan komputer atau laptop lebih dari 8 jam sehari, keadaan ini menyebabkan penglihatan mengalami gangguan yaitu computer vison syndrome. Berdasarkan permasalahan di atas maka perlu melakukan suatu kegiatan penyuluhan terkait pengetahuan mengenai CVS ini. Kegiatan ini bertujuan untuk meningkatkan derajat kesehatan individu, mengedukasi agar memperhatikan kesehatan mata dan menambah wawasan dengan memberikanedukasi terkait pengetahuan CVS dan tindakan preventif untuk mengurangi kejadian CVS ini. Target kegiatan adalahmasyarakat terutama dewasa muda yang dalam aktivitas sehari-hari menggunakan komputer. Kegiatan pelaksanaan dilakukan pada tanggal 10 April 2021 dan diikuti oleh 35 orang peserta, yang sebagaian besar berupa mahasiswa. Hasil kegiatan bakti kesehatan ini menunjukkan adanya peningkatan pengetahuan peserta mengenai penyakit CVS ini.Hal ini terlihat dari adanya peningkatan pengetahuan sebesar 50\% dari hasil pretes dan postes. Peningkatan pengetahuan ini diharapkan dapat membuat para pengguna komputer lebih menyadari bila munculnya kelainan - kelainan mata tersebut dan dapat mencari pertolongan sehingga tidak terjadi gangguan dikemudian hari.
\end{abstract}

Kata kunci: computer vision syndrome, penyuluhan, preventif

\section{PENDAHULUAN}

Meningkatnya penggunaan komputer telah menyebabkan berbagai gejala mata yang meliputi ketegangan mata, mata lelah, iritasi, kemerahan, penglihatan kabur, dan diplopia. Kumpulan dari keluhan tersebut disebut sebagai Computer Vision Syndrome (CVS). CVS tidak hanya berdampak signifikan pada kenyamanan visual tetapi juga pada produktivitas kerja, karena $90 \%$ pengguna komputer waktu lama mengalami gejala visual seperti ketegangan pada daerah mata sehingga menimbulkan nyeri kepala, mata terasa kering, penglihatan ganda dan gangguan penglihatan untuk jarak dekat atau maupun jauh. (Rosenfield, 2011). 
Computer vision syndrome disebabkan penggunaan komputer, tablet, e-reader, dan smartphone dengan intensitas lama dan terus menerus sehingga membuat beban pada penglihatan. (American Optometric Association, 2017). Interaksi dengan layar computer jangka panjang, monitor yang silau, pencahayaan yang tidak adekuat atau kontras kurang maksimal berakibat beban visual melebihi batas normal penglihatan menyebabkan timbulnya kelelahan disertai kekeringan mata (Akinbinu \& Mashalla, 2014).

Secara global prevalensi CVS sekitar 60 juta orang dan angka ini akan bertambah jumlah kasus tiap tahunnya (Ranasinghe et al., 2016). Di era sekarang, ponsel dan perangkat tampilan digital lainnya merupakan suatu hal penting dalam kehidupan sehari-hari. Tetapi karena pandemi Covid-19 penggunaan gadget digital meningkat dengan pesat. Penggunaan gadget berhubungan langsung untuk peningkatan risiko kesehatan mata. Dalam penelitan yang dilakukan Niveditha \& Dheepak (2020) yang bertujuan untuk menilai prevalensi, faktor risiko dan gejala sindrom penglihatan digital (DVS) selama lockdown Covid-19 menunjukkan hasil bahwa waktu atau jam yang dihabiskan tentang penggunaan layar digital oleh responden meningkat secara signifikan serta keluhan yang dilaporkan adalah tidak enak di kepala, disertai ketegangan mata dan mata terasa kering.

Di dunia kerja saat ini, penggunaan komputer dan penggunaan perangkat digital tidak terbatas pada pekerja kantoran, tetapi terjadi di kegiatan sekolah, laboratorium dan lain-lain. CVS adalah masalah kesehatan yang diakui oleh American Optometric Association (2017) yang dapat menyebabkan kelelahan mata, sakit kepala, penglihatan kabur serta rasa terbakar, gatal dan mata kering akibat penggunaan komputer, tablet, ponsel, dan perangkat layar digital lainnya yang berkepanjangan. Aktivitas dengan menggunakan komputer lebih menuntut visual daripada jenis pekerjaantanpa pemakaian komputer. Gambar pada layar komputer berbeda dari jenis gambar yang biasa dilihat mata dengan materi cetakan, tidak seperti teks yang dicetak, setiap gambar atau huruf pada layar komputer terdiri dari piksel kecil cahaya yang paling terang di bagian tengah dan menjadi lebih redup ke arah tepi piksel. Sesorang saat melihat layar komputer, secara tidak sadar mata berulang kali berusaha untuk beristirahat dengan menggeser fokus mata ke suatu titik di luar layar, mata harus terus menerusfokus kembali ke layar komputer dan terjadi peralihan konstan antara layar dan titik relaksasi dan kondisi ini menciptakan kelelahan mata dan kelelahan. CVS juga dapat disebabkan layar digital seperti resolusi, kontras layar, kecepatan refresh gambar dan flicker, silau layar serta jarak dan sudut pandang di layar (Motchan, 2018).

Tanda dan gejala keluhan CVS yaitu: asthenopia, sakit mata dan kepala, penglihatan kabur yang intermi sensen, sensasi terbakar, kelemahan keseluruhan terutama di area leher dan bahu. (Ranasinghe et al., 2016). Patofisiologi tanda dan gejala CVS termasuk akomodasi, permukaan okuler dan otot ekstra okuler. Keluhan CVS yang timbul dari masalah akomodasi antara lain penglihatan kabur terutama pada penglihatan dekat dan ganda. Keluhan yang muncul dari area kedua (permukaan okuler) meliputi kekeringan pada mata yang dapat menyebabkan sensasi terbakar atau pedas; sedangkan yang berasal dari area ketiga (otot ekstra-okular) adalah kepala, leher, bahu, dan nyeri secara keseluruhan. (Logaraj et al.,2014).

Ramzan (2016) dalam studinya mengamati bahwa mayoritas pengguna komputer hadir dengan keluhan ini setelah penggunaan komputer yang diperpanjang. Comptuter vision syndrome merupakan penyakit tidak menular yang meningkat serta memiliki kapasitas sebagai ancaman kesehatan masyarakat jika tidak ada perhatian serius. Pencegahan CVS paling tepat adalah preventif dan kuratif.

Salah satu aturan penting untuk mencegah CVS khususnya bagi pengguna komputer adalah aturan 
20-20-20. Liao \& Drury (2000) mendeskripsikan aturan ini dengan memalingkan muka dari layar setiap 20 menit pada jarak 20 kaki selama 20 detik. Beberapa cara lain untuk mencegah CVS melibatkan pengaturan lingkungan kantor yang tepat, posisi ideal yang berkaitan dengan kedekatan dan sudut yang dibuat tubuh anda dengan komputer, ketinggian kursi dan meja, dan sebagainya. Ilmu ergonomimemperhitungkan postur kesadaran saat bekerja dengan komputer, jarak (dari mata ke layar, meja, kursi, dll) sudut (siku, lutut, pinggul, dll). (Rahman \& Sanip, 2011; Sa' et al., 2013).

Penglihatan yang kurang baik membuat performa seseorang menjadi buruk berakibat penurunan produktivitas (Anshel, 2005). Penerapan pembelajaran jarak jauh diperlakukan pada kegiatan pembelajaran di sekolah maupun perguruan tinggi karena pencegahan dalam pandemi yang terjadi. $70 \%$ dari orang yang menggunakan komputer mengalami keluhan terhadap penglihatan dan $90 \%$ anak di USA dalam aktivitas pembelajaran memakai komputer di rumah dan di sekolah dengan frekuensi yang berlebihan (Rosenfield, 2011).

Di masa pandemi berkepanjangan sebagian besar kegiatan aktivitas masyarakat dilakukan di dalam rumah, dan sering menggunakan smartphone, laptop, menonton televisi. Intensitas tinggi, frekuensi yang sering serta tidak terkontrolnya pemakaian gadget menimbulkan gangguan pada penglihatan sehingga dapat menyebabkan angka kejadian computer vision syndrome meningkat tajam.

\section{METODE PELAKSANAAN PKM}

Pelaksanaan kegiatan meliputi penyuluhan dengan materi CVS, tindakan preventif dalam mengurangi gejala CVS seperti menempatkan jarak mata serta posisi duduk dengan tepat, mengatur cahaya yang adekuat, memasang antisilau di layar, melaksanakan 20-20-20 yaitu setiap 20 menit mata diistirahatkan dengan mengalihkan mata dari layar komputer atau melihat objek jauh dengan jarak $20 \mathrm{kaki}$, dilakukan selama 20 detik. Target kegiatan adalah masyarakat yang dalam aktivitas sehari-hari menggunakan komputer. Penyuluhan kesehatan adalah kegiatan penyampaian edukasi kesehatan sehingga masyarakat mendapatkan informasi kesehatan serta menambah wawasan secara jelas, mudah dipahami dan bermanfaat bagi kehidupannya.

Penyuluhan dilakukan dengan sistem daring. Peserta penyuluhan yang sudah terdaftar diberikan link zoom sehingga dapat mengikuti acara penyuluhan. Sebelum mengikuti kegiatan bakti kesehatan ini, peserta harus melakukanpendaftaran dengan menggunakan formulir elektronik yang telah disedikan oleh panitia. Formulir pendaftaran tersebut kemudian disebarkan melalui flyer yang telah dibuat oleh panitia, flyer tersebut disebarkan 2 minggu sebelum kegiatan bakti kesehatan melalui perwakilan dari anggota penyuluhan. Flyer kegiatan dapat dilihat pada Gambar 1 .

Persiapan kegiatan yaitu menyiapkan materi kegiatan bakti kesehatan, melakukan penyuluhandan tanya jawab. Panitia pengabdian membagikan kuisioner penilaian yang terdiri dari pretest dan post test serta umpan balik dari kegiatan penyuluhan. Pre test dan post test dilakukan melalui google form yang dikirimkan melalui chat room Zoom. Peserta diberikan sejumlah pertanyaan terkait CVS, peserta diberikan kesempatan untuk menjawab pertanyaan terkait CVS. Pertanyaan pretest dan post test dibuat sama, adapun aspek yang dievaluasi meliputi: efektvitas pelaksanaan dilihat dari: manfaat kegiatan, tingkat pengetahuan dan pemahaman terkait materi penyuluhan

\section{HASIL DAN PEMBAHASAN}

Rangkaian pelaksanaan kegiatan bakti kesehatan dibagi menjadi 2 bagian, yaitu bagian persiapan pelaksanaan kegiatan dan hasil kegiatan bakti kesehatan. Sebelum dimulai kegiatan bakti 
kesehatan, dilakukan rapat persiapan terlebih dahulu. Rapat persiapan dilakukan dilakukan pada tanggal 23 Maret 2021, dalam rapat tersebut tim mendiskusikan mengenai waktu pelaksanaan, cara penyebaran flyer, besar biaya yang akan diberikan kepada peserta, pembuatan flyer beserta soal pre tes dan pos tes. Selain itu dilakukan penentuan moderator dan penyusunan jadwal kegiatan. Dalam rapat persiapan, tim juga mendiskusikan mengenai waktu pelaksanaan bakti kesehatan. Tim menetapkan waktu pelaksanaan bakti kesehatan dilaksanakan tanggal 10 April 2021, pukul $10.00-12.00$ WIB.

Pelaksanan kegiatan bakti kesehatan diselenggarakan sesuai dengan tanggal yang telah ditetapkan, yaitu pada hari Sabtu, tanggal 10 April 2021. Tim mulai bergabung ke dalam aplikasi zoom meeting mulai pukul 09.30 WIB. Hal ini dilakukan supaya tim dapat melakukan persiapan sebelum kegiatan di mulai. Tepat pukul 10.00 WIB, seluruh peserta yang telah melakukan pendaftaran diijinkan mulai bergabung dalam zoommeeting untuk mulai mengikuti kegiatan bakti kesehatan. Acara kegiatan bakti kesehatan dibuka oleh dr. Enny Irawaty sebagai moderator.

Sebelum kegiatan di mulai, peserta diberikan soal pretes untuk menilai tingkat pengetahuan peserta sebelum diberikan penyuluhan. Setelah sesi pretes selesai, dr. Meriana memulaikegiatan penyuluhan mengenai computer vision syndrome. Sebanyak 35 orang peserta yang mengikuti acarabakti kesehatan ini. Dr. Meriana memberikan penyuluhan, kegiatan dilanjutkan dengan tanya jawab, peserta penyuluhan memberikan pertanyaan kepada narasumber, yang dapat dinyampaikan secara langsung maupun dapat disampaikan melalui chat room yang telah disediakan. Pertanyaan yang banyak diajukan terkait CVS, cara pencegahannya, metode 20-2020. Pelaksanaan kegiatan PKM dapat dilihat pada Gambar 2 dan Gambar 3.

\section{Gambar 1}

\section{Flyer Kegiatan}

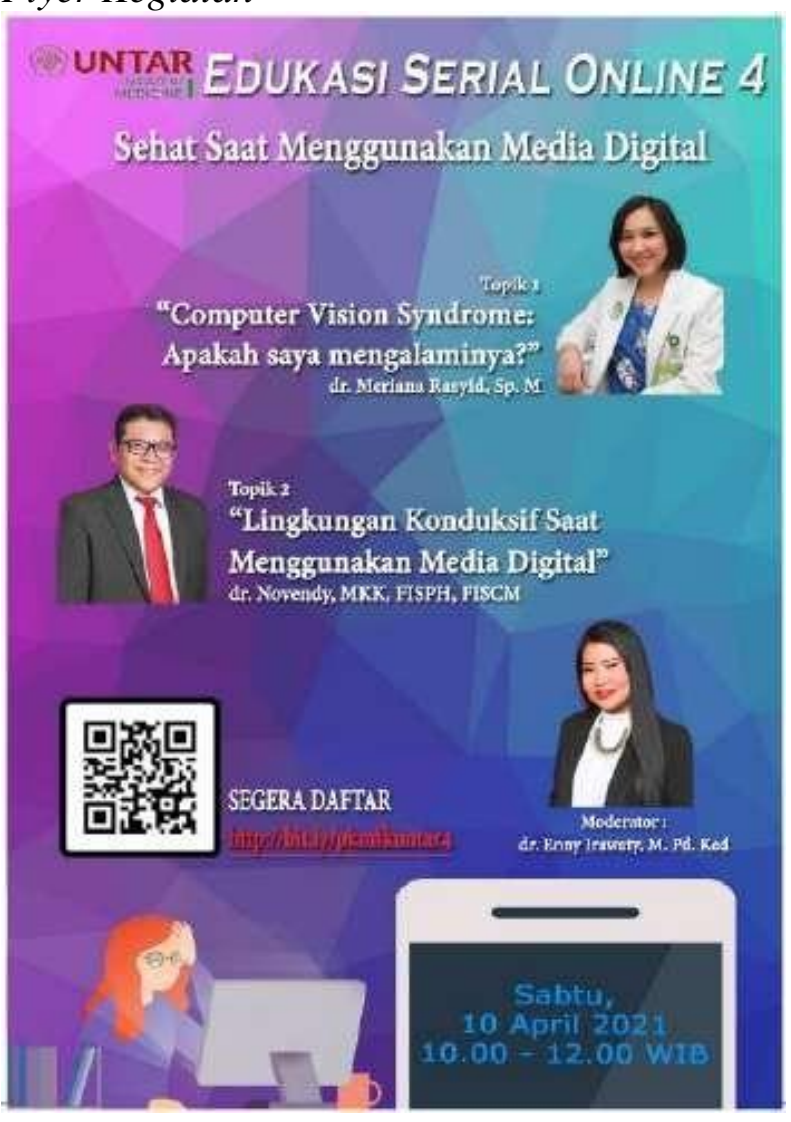




\section{Gambar 2}

Penyampaian Materi oleh Narasumber

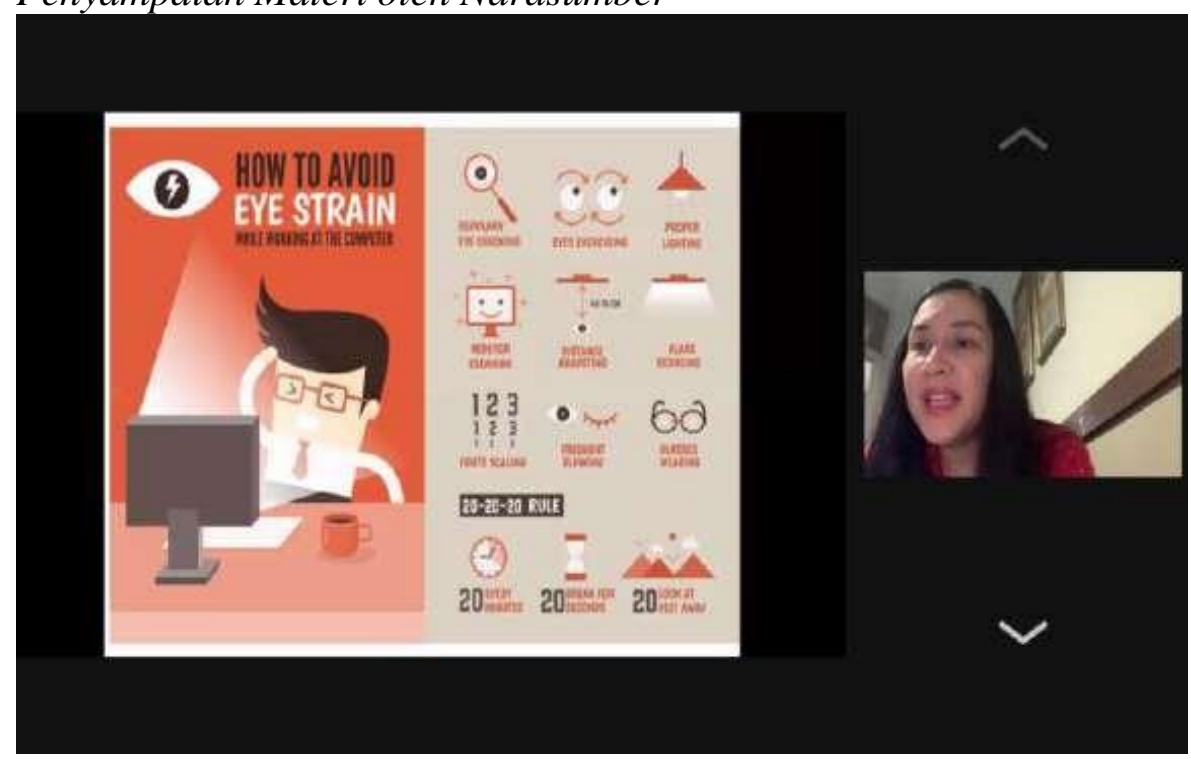

\section{Gambar 3}

\section{Peserta Kegiatan Bakti Kesehatan}

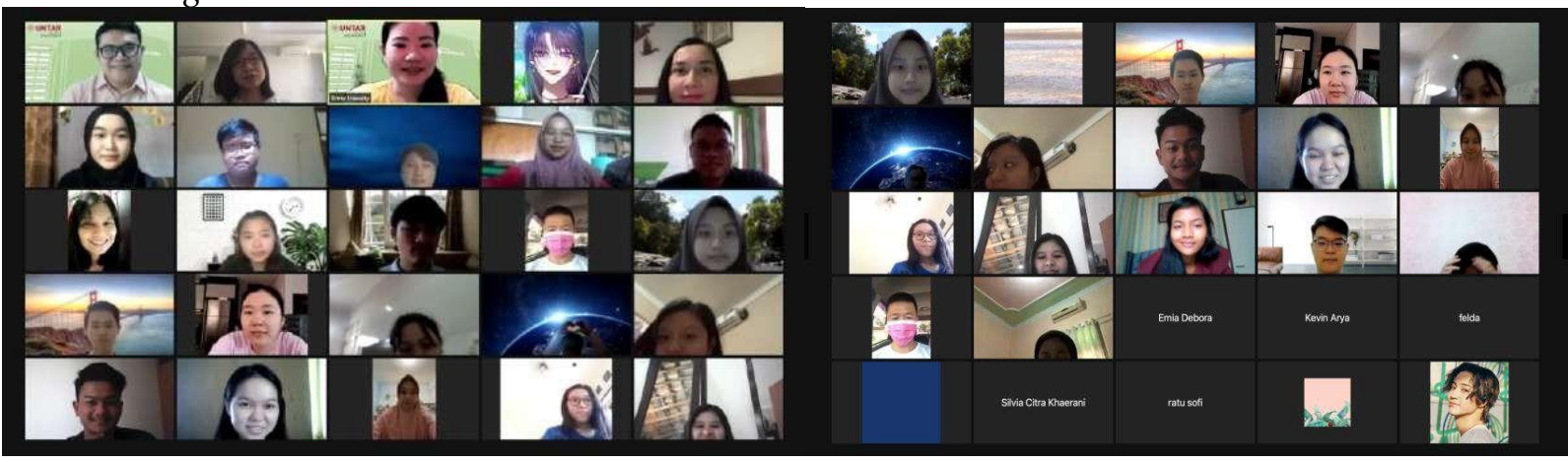

Pada akhir kegiatan, peserta diminta mengisi soal pos tes yang telah disiapkan. Hal ini dilakukan untuk menilai apakah terjadi peningkatan pengetahuan dari peserta mengenai materi penyuluhan yang telah disampaikan. Dari 35 peserta yang mengikuti kegiatan ini didapatkan hasil pre tes didapatkan bahwa nilai rata - ratanya adalah 40 dan hasil pos tes didapatkan nilai rata - rata sebesar 60. Dari hasil pre tes dan pos tes tersebut didapatkan adanya peningkatan pengetahuan terkait CVS dan pencegahannya sebanyak 50\%. Peserta PKM memberikan umpan balik bahwa kegiatan PKM ini meningkatkan pengetahuan peserta serta membuat para pengguna komputer lebih menyadari bila munculnya kelainan - kelainan mata tersebut dan dapat mencari pertolongan sehingga tidak terjadi gangguan dikemudian hari.

\section{KESIMPULAN DAN SARAN}

Penggunaan komputer selama masa pandemi terutama untuk pembelajaran semakin meningkat. Computer vision syndrome merupakan penyakit tidak menular, perlu preventif dan kuratif CVS untuk menambahpengetahuan dalam bidang kesehatan terutama sangat dibutuhkan pada masa pandemi ini.

Ucapan Terima Kasih (Acknowledgement)

Terima kasih kami disampaikan kepada Lembaga Penelitian dan Pengabdian kepada Masyarakat 
Universitas Tarumanagara atas pendanaan dalam kegiatan ini. Terima kasih juga disampaikan kepada seluruh peserta yang berpartisipasi dalam kegiatan bakti kesehatan, sehingga kegiatan dapat dilakukan sesuai rencana. Terima kasih juga disampaikan kepada Pimpinan Universitas Tarumanagara dan Pimpinan Fakultas Kedokteran Universitas Tarumanagara atas dukungannya dalam pelaksanaan kegiatan bakti kesehatan ini.

\section{REFERENSI}

American Optometric Association. (2017). Computer vision syndrome. American Optometric Association. https://www.aoa.org/healthy-eyes/eye-and-vision-conditions/computervision-syndrome

Anshel, J. (2005). Visual ergonomics handbook. Taylor and Francis Group.

Akinbinu, T. R. \& Mashalla, Y. J. (2014). Medical practice and review impact of computer technology on health: computer vision syndrome (CVS). Acad Journals, 5(3), 20-30. https://academicjournals.org/journal/MPR/article-full-text-pdf/0905F9948599

Niveditha, K. P. \& Dheepak, S. M. (2020). Digital vision syndrome (DVS) among medical students during Covid-19 pandemic curfew. International Journal of Research in Pharmaceutical Sciences, 11(SPL 1), 1128-1133. www.pharmascope.org/ijrps

Logaraj, M., Madhupriya, V. \& Hedge, S. (2014) Computer vision syndrome and associated factors among medical and engineering students in Chennai. Ann, Med. Health Sci. Res., 4(2), 179-1854. https://www.bibliomed.org/?mno=31577

Liao, M.H., Drury, C.G. (2000). Posture, discomfort and performance in a VDT task. Ergonomics 43, 345-598. https://pubmed.ncbi.nlm.nih.gov/10755658/

Motchan, B. (2018). Computer vision syndrome decreases worker productivity. EHS Today. https://www.ehstoday.com/ppe/article/21919632/computer-vision-syndrome-decreasesworker- productivity

Ramzan, S. (2016). Impact of Computer Vision Syndrome On Health Of Computer Usage Bank Employee, IJRDO. 2(7), 40-537. https://www.ijrdo.org/index.php/cse/article/view/778

Rahman, Z. A. \& Sanip, S. (2011). Computer vision syndrome: the association with ergonomic factors. BMJ, 65(1), 3579. https://www.ncbi.nlm.nih.gov/pmc/articles/PMC3991936/

Ranasinghe, P, Wathurapatha, W. S., Perera, Y. S., Lamabadusuriya, D. A., Jayawardana, N. \& Katylanda, P. (2016). Computer vision syndrome among computer office workers in a developing country: An evaluation of prevalence and risk factors. BMC Res. Notes 9, 1503. https://pubmed.ncbi.nlm.nih.gov/26956624

Rosenfield, M. (2011). Computer vision syndrome: A review of ocular causes and potential treatments. Ophthalmic Physiol Opt, 31(5), 502-15. doi: 10.1111/j.14751313.2011.00834.x. Epub 2011 Apr 12. PMID:21480937

Sa' E. C. S., Junior, S., Leite, M. (2013) Computer vision syndrome (CVS) in administrative professionals and the evaluation of ergonomic conditions of the workplace. BMJ, $70(1)$, 13810. https://www.ajol.info/index.php/jnoa/article/view/189347/178582 